\title{
Historical Account of the American Pediatric Society John Howland Award
}

\author{
THOMAS F. BOAT \\ Department of Pediatrics, Cincinnati Children's Hospital Medical Center, and Cincinnati Children's \\ Research Foundation, 3333 Burnet Avenue, Cincinnati, OH 45229-3039, U.S.A.
}

Much of the information for this brief historical account of the Howland Award was compiled by our 2002 Howland Awardee, Dr. Howard A. Pearson, from APS records and related in a book he authored, The Centennial History of the American Pediatric Society. The Howland Award has been recognized for many years as the highest honor bestowed upon a pediatrician by the APS and may be the most coveted award in all of pediatrics. Its prominence and prestige were less apparent at the onset, 50 years ago. At that time, the society was a more select, more closely knit organization with fewer than 200 members.

The Howland award was established as a result of remarkable discussions and actions by the APS at its annual business meeting at the Traymore Hotel in Atlantic City on May 3, 1951. During these days in the middle of APS history, the business meetings were well attended and marked by animated and sometimes contentious discussions. The minutes of these discussions were transcribed verbatim.

The president of the APS Council was Daniel Darrow, who was then on the pediatric faculty at Yale. Darrow reported that the APS Council had received a letter from the president of $M$ \& R Dietetics Laboratory (that later became Ross Laboratories) offering to make an annual donation of $\$ 1,000$ for an award and medal to be given "to a man distinguished in pediatrics." Darrow reported that the council had decided to decline this offer for two reasons. First, because it might appear to have commercial implications; and second, because there were already existing pediatric awards - the Mead-Johnson and Borden Awards of the American Academy of Pediatrics.

A number of APS members then spoke persuasively in favor of such an award. L. Emmett Holt, Jr., of New York emphasized that there were no strings attached to the donation and that it was offered "without commercial mention or implications." It would be awarded by the APS, and the society would decide what it would be named. Holt further suggested that this new award would be analogous to the prestigious Korber Award of the Association of American Physicians. Charles Janeway of Boston also supported establishing a

Received June 17, 2002; accepted July 24, 2002

Correspondence: Thomas F. Boat, M.D., Department of Pediatrics, Cincinnati Children's Hospital Medical Center, Cincinnati Children's Research Foundation, 3333 Burnet Avenue, Cincinnati, OH 45229-3039; e-mail: Thomas.Boat@chmcc.org

Presented at the 2002 Annual Meeting of the Pediatric Academic Societies, Baltimore, Maryland, U.S.A.

DOI: 10.1203/01.PDR.0000052079.91589.7A new pediatric award. He pointed out that the Mead-Johnson and Borden Awards were principally given for research accomplishments, but this new award might be given instead for "distinguished service to pediatrics as a whole." Rustin McIntosh of New York and Alan Butler of Boston strongly supported Holt and Janeway's position. It is interesting that Holt, McIntosh, Janeway, and Butler all subsequently received the Howland Award.

George Guest of Cincinnati then made a motion that the next APS President, Dr. Hugh McCulloch of Montgomery, AL, appoint an ad hoc committee that would be empowered to act in "deciding how the award should be administered and how it shall be designated." This motion carried overwhelmingly.

The Committee's composition is not recorded, but it probably was the APS Council. The offer from $M \& R$ was promptly accepted. The award was named the John Howland Award. It was authorized under the amended Article II of the APS Constitution, which stated that a purpose of the SOCIETY was to "honor those who by their contributions to pediatrics have aided in its advancement." Note the wording. The award is for distinguished service to pediatrics as a whole, rather than research or other specific scholarly or clinical activities. A handsome bronze medal was struck showing Dr. Howland in profile on the face, and on the obverse, the name of the awardee and the words "for distinguished service to Pediatrics."

At the next meeting of the APS at the Hotel Chamberlin in Old Comfort, VA, on May 8, 1952, the first Howland Medal was awarded to Edwards Park of Johns Hopkins and the Harriet Lane Home. Park was introduced by Grover F. Powers. Appropriately, both Park and Powers trained under John Howland in Baltimore. Fifty-two subsequent awardees have joined Dr. Park, there being dual awards on two occasions. The first woman awardee was Dr. Ethel C. Dunham in 1957.

Since 1976, a formal dinner has honored the Howland Awardee. This event, on the evening of the presentation, has evolved from an intimate gathering to a celebration, open to all APS members.

The 52 Howland Awardees are:

1952 Edwards A. Park

1953 Grover F. Powers

1954 Bela Schick

1955 James L. Gamble

1956 Harold K. Farber

1957 Ethel C. Dunham

1958 Irvine McQuarrie 
1959 Daniel C. Darrow

1960 Bronson Crothers

1961 Rustin McIntosh

1962 Joseph Stokes, Jr.

1963 Lawson Wilkins

1964 Samuel Z. Levine

1965 John Caffey

1966 Emmett Holt, Jr.

1967 Martha M. Eliot

1968 Paul Gyorgy

1969 Allen M. Butler

1970 Joseph Warkany

1971 Helen B. Taussig

1972 Waldo E. Nelson

1973 Louis K. Diamond

1974 Albert B. Sabin

1975 Harry H. Gordon and Roland B. Scott

1976 Clement A. Smith

1977 A. Ashley Weech

1978 Charles A. Janeway

1979 Amos U. Christie

1980 C. Henry Kempe
1981 Saul Krugman

1982 Horace L. Hodes

1983 Helen C. and Harold E. Harrison

1984 Henry L. Barnett

1985 Wolf W. Zuelzer

1986 Richard L. Day

1987 Robert A. Good

1988 Joseph Dancis

1989 Barton Childs

1990 Julius Richmond

1991 Robert E. Cook

1992 Gilbert B. Forbes

1993 Lewis A. Barness

1994 Sydney S. Gellis

1995 Floyd W. Denny, Jr.

1996 Mildred T. Stahlman

1997 Melvin M. Grumbach

1998 Robert J. Haggerty

1999 Abraham M. Rudolph

2000 Samuel Katz

2001 Delbert A. Fisher

2002 Howard A. Pearson 